\title{
Studying the Possibility of Using Some Mono- and Polycyclic Hydrocarbons of Oils on the Absheron Peninsula as Genetic Indicators in Conducting Ecological Expertise
}

\author{
E. R. Babayev, ${ }^{\mathrm{a} @ ~ P . ~ S h . ~ M a m m a d o v a, ~}{ }^{a}$ U. F. Hashimova, ${ }^{\mathrm{b}}$ V. A. Adigozalova, ${ }^{\mathrm{b}}$ \\ and I. M. Eyvazova ${ }^{a}$ \\ a Academician A.M. Guliyev Institute of Chemistry of Additives, Azerbaijan National Academy of Sciences, AZ1029 Baku, \\ Azerbaijan \\ bA.I. Karayev Institute of Physiology, Azerbaijan National Academy of Sciences, AZ1100 Baku, Azerbaijan \\ ${ }^{\circledR}$ Corresponding author E-mail: elbeibabaev@yahoo.de
}

\begin{abstract}
The research purpose was studying the possibility of using some mono- and polycyclic hydrocarbons of oils on the Apsheron Peninsula as genetic indicators (biomarkers). The oil extracted from oil-contaminated soils from the Balakhany deposit on the Absheron Peninsula was investigated. The oil contamination was analyzed by chromatographymass spectrometry method. Low sulphur Azeri oils contain the important relict hydrocarbons such as nickel and vanadyl porphyrins. For the oil from the Balakhany deposit there was revealed the presence of homologous series of n-alkylcyclohexanes and n-alkylcyclopentanes, and the relationships between methylcyclohexane and the sum of cyclopentane hydrocarbons was studied. $C_{10}$ bicyclanes and their methyl homologues were determined in the investigated oil. Tricyclic saturated hydrocarbons belong to the class of naphthenes which consist of the significant part of oil hydrocarbons. Adamantane and its closest homologues (1-, 1,3- and 1,3,5-methylsubstituted adamantanes) relating to the tricyclic saturated hydrocarbons were identified in the investigated oil. In the oils of the Absheron Peninsula there were also found the tetracyclic structures with cyclopentanoperhydrophenanthrene system as the core, i.e. these compounds belong to the sterane hydrocarbons, the ratio of which for Balakhani oil is $C_{27}: C_{28}: C_{29}=28: 33: 38$. For oil gopans, a fragment ion $\mathrm{m} / \mathrm{z}=191$ characteristic for them was revealed. For hydrocarbons of a number of gopans of $C_{31}$ composition and higher, i.e. in cases when $C$-22 atom becomes chiral, there may be two epimers that differ in $R$ or $S$ configuration of $C$-22 chiral center. In the initial biogopans of $C_{31}$ composition and higher, $C-22$ atom has a strictly defined $R$ configuration. It appears in a number of doublet peaks characteristic for chromatograms of mixed oil gopans. Comparison of biomarker mass fragmentograms of the investigated relict hydrocarbons, including steranes ( $/ 2 / 2$ 217) and gopans $(\mathrm{m} / \mathrm{z} 191)$ showed that they retain the composition almost identical to the composition of the initial oil during the experiment.
\end{abstract}

Keywords: Relict hydrocarbons, steranes, gopans, porphyrins, chromatography-mass spectrometry.

\section{Introduction}

The hydrocarbon composition of the oils reflects the nature and conditions of the processes occurring during their formation. The problem of oil research remains one of the most important one, both from the point of view of the source of individual hydrocarbons, the scientific and technical classification of oil raw materials, and from the point of view of purely geological and geochemical problems.

By today the petroleum literature has been very rich in valuable materials and monographs covering various aspects of this problem. Azerbaijani oils have become objects of research of famous scientists almost simultaneously with the discovery of their deposits. ${ }^{[1-5]}$ Researches of the scientists relate to the study of the composition and properties of oils, their fractions, individual hydrocarbon composition and are aimed at solving a number of theoretical and practical issues related to the problem of extraction, processing and rational use of oils, as well as a more rigorous scientific classification of oil raw materials. As a result of the studies carried out with the use of modern physicochemical methods of analysis, including UV, IR, ${ }^{1} \mathrm{H}$ NMR, EPR, mass spectrometry, gas and liquid chromatography, the structure-group composition of high-molecular heteroatom compounds typical for oils of Azerbaijan and their vacuum residues has been studied. The found patterns are explained from the standpoint of modern ideas about the genesis of oils..$^{[3]}$

To establish the chemism of the processes of oil transformation under the influence of natural and climatic factors, it is important to study such hydrocarbons that have retained the structure of the initial organic material. Studying so-called relict hydrocarbons - biological markers or biomarkers is of particular interest. ${ }^{[6,7]}$ The composition of biomarkers is a "fingerprint" for a specific deposit and is never repeated. Oil biomarkers are represented by hydrocarbons of different classes: alkanes, naphthenes and arenas. Compounds of the isoprenoid structure take an important place. 


\title{
Изучение возможности использования некоторых моно- и полициклических углеводородов нефтей Апшеронского полуострова в качестве генетических показателей при проведении экологических экспертиз
}

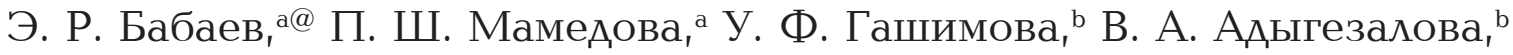 \\ И. М. Эйвазова ${ }^{a}$ \\ аинститут химии присадок им. академика А.М. Кулиева НАН Азербайджана, АZ1029 Баку, Азербайджан \\ ${ }^{\mathrm{b}}$ Институт физиологии им. А.И. Караева НАН Азербайджана, АZ1100 Баку, Азербайджан \\ ${ }^{\circledR}$ E-mail: elbeibabaev@yahoo.de
}

\begin{abstract}
Целью настоящей работы было изучение возможности использования некоторых моно- и полициклических углеводородов нефтей Апшеронского полуострова в качестве генетических показателей (биомаркеров). В работе исследована нефть, выделенная из нефтезагрязненных почв месторождения Балаханы Апшеронского полуострова. Нефтезагрязнения анализировали методами хромато-масс-спектрометрии. Одними из важных реликтовых соединений малосернистых азербайджанских нефтей являются никелевые и ванадильные порфирины. Для нефти Балаханского месторождения выявлено наличие серий гомологических рядов н-алкилциклогексанов и н-алкилциклопентанов, изучены соотношения между метилциклогексаном и суммой ицклопентановых углеводородов. Среди бицикланов в исследованной нефти определень бициклань $C_{10}$ и их метильные гомологи. Трициклические насыщенные углеводороды относятся к классу нафтенов, составляюших значительную массу углеводородов нефти. Идентифицированы адамантан и его ближайшие гомологи: 1-, 1,3и 1,3,5-метилзамещенные адамантаны. В нефтях Апшеронского полуострова найдены тетрациклические структуры, в основе ядра которых лежит система ичиллопентанопергидрофенантрена, т.е. эти соединения принадлежат к стерановым углеводородам, соотношение которых для Балаханской нефти составляет $C_{27}: C_{28}: C_{29}=28: 33: 38$. Для нефтяных гопанов выявлен характерный для них фрагментный ион $m / z \quad 191$. Для углеводородов ряда гопанов состава $C_{31}$ и выле, т.е. в тех случаях, когда атом С-22 становится хиральным, образуются два эпимера, отличаюшиеся $R$ или $S$ конфигурацииейхирального ичентра $C$-22, что проявляется в ряде дублетных пиков, характерных для хроматограмм смеси нефтяных гопанов. Сопоставление биомаркерных масс-фрагментограмм исследуемых реликтовых углеводородов, в том числе стеранов (m/z 217) и гопанов (m/z 191) показало, что они сохранили состав практически идентичный составу исходной нефти.
\end{abstract}

Ключевые слова: Реликтовые углеводороды, стераны, гопаны, порфирины, хромато-масс-спектрометрия.

\section{Experimental}

As a research object oil extracted from oil-contaminated soils of the Balakhany deposit on the Absheron Peninsula was used.

Gas chromatography and mass spectrometric analyses were performed on a Thermo Quest MD-800 GC 8000 Series GC/MS device with using an Fision AS 800 autosampler. One ml of the sample was injected into the Splitless-mode injector at $280{ }^{\circ} \mathrm{C}$. A gaschromatographic capillary column (ED-VRX5 0.25 from SGEB) with a length of $30 \mathrm{~m}$ and an internal diameter of $0.25 \mathrm{~mm}$ was used. The carrier gas was helium. The temperature was raised from $80^{\circ} \mathrm{C}$ to $300{ }^{\circ} \mathrm{C}$ at a rate of $4{ }^{\circ} \mathrm{C}$ per minute.

The interpretation of gas chromatograms and mass spectra was carried out with use of the Mass-lab TM 4.1.3 computer program. Quantitative control of the investigated substances was carried out by integrating the peak areas and comparing them with the integrated areas of the standard, for example, for aromatics, 1,1-binaphthenes $\left(\mathrm{C}_{20} \mathrm{H}_{14}\right)$ or squalane $\left(\mathrm{C}_{30} \mathrm{H}_{62}\right)$ for the alkane fraction.

\section{Results and Discussion}

Among a great variety of organic compounds identified in oils, tetrapyrrole compounds, related to chlorophylls and gemins, which perform the most important functions of living systems, take a special place. They are present in oils in the form of metalloporphyrins. ${ }^{[8]}$ It follows from literary sources that the composition and structure of oil porphyrins are largely similar. Porphyrins are compounds in which four pyrrole rings are linked together via methine $(-\mathrm{C}=)$ bridges into a single cyclic conjug ate system, which is based on a 16-membered macrocycle comprising 4 nitrogen atoms. As a substituent, radicals of limiting, unsaturated hydrocarbons, acids, esters, aldehydes, aromatic compounds, etc. can act. More often, porphyrins are in the form of metal complexes formed by the substitution of imine hydrogens with a metal, for example, magnesium in chlorophylls, iron in hemoglobin. ${ }^{[9]}$

Porphyrins are contained in oils in the form of complexes of vanadium - vanadyl porphyrins $\left(\mathrm{VO}^{2+}\right)$ (Figure 1) and nickel - nickel porphyrins $\left(\mathrm{Ni}^{2+}\right)$. The main feature of oil metalloporphyrins is that they are considered as biomarkers of oil, i.e. analogues of hydrocarbons, which have retained the features of the structure of the initial bioorganic molecules. ${ }^{[6-9]}$

Oil porphyrins being optically active products rotate the plane of polarization to the left. The presence of optical activity in these molecules gives grounds to consider 
them products of living origin. The similarity and kinship of plants, animals and organic substances of similar structures in organisms, as well as the role of porphyrins as relict oil hydrocarbons (biomarkers), testify to the organic nature of the origin of oil.

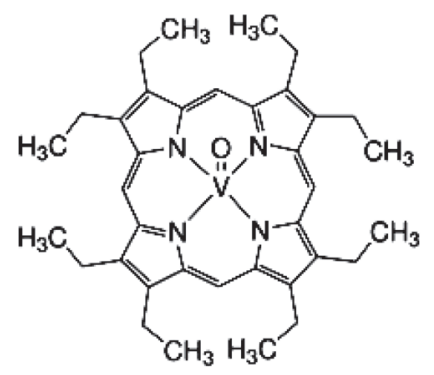

Figure 1. Vanadyl porphyrin.

Metal porphyrins in the distillation process accumulate in residual fractions boiling above $300{ }^{\circ} \mathrm{C}$, especially in oil residues.

Isolation of porphyrins from Azerbaijani oils was carried out by hot extraction with ethyl alcohol according to the known method. ${ }^{[3,10]}$ Taking into account the insignificant content of porphyrins in Azerbaijani oils, subsequent experiments were carried out with a large amount of oil (3-10 $\mathrm{g}$ instead of $1 \mathrm{~g}$ of oil). However, in the extracts obtained, only traces of porphyrins were observed. ${ }^{[3]}$

Unlike sulfurous oils, in the low-sulfur oils of Azerbaijan, there is extremely small amount of porphyrin complexes. ${ }^{[1]}$

It is known that low-paraffin oils on the Absheron Peninsula tend to be rich in alicyclic hydrocarbons. ${ }^{[1-3]}$ It is these hydrocarbons that determine the place of oils in a number of natural organic compounds. A characteristic feature of them is a low content of asphaltenes and a high content (over $40 \%$ per oil) of light fractions. In the saturated hydrocarbon oils, naphthenes predominate and make up more than $70 \%{ }^{[3,5]}$ It should be noted that the oil of each oil-bearing region is characterized by specific set of genetic indicators determined mainly by the conditions of formation of oilbearing rocks and hydrocarbon generation processes. ${ }^{[6]}$

The research purpose was to study the possibility of using some mono- and polycyclic hydrocarbons of the oil on the Apsheron Peninsula, in particular, the oil from the Balakhany field, as genetic indicators in conducting environmental assessments

At present there are numerous data on the content of various monocyclic naphthenes in oils, which, for the most part, are concentrated in a single polycyclic block.

The evidence for the presence of homologous series of $n$-alkylcyclohexanes and $n$-alkylcyclopentanes in the investigated oils is mass chromatograms (fragmentograms) recorded for the most characteristic fragment ions $m / z 69$ for $n$-alkylcyclopentanes and $m / z 83$ for $n$-alkylcyclohexanes (Figure 2).

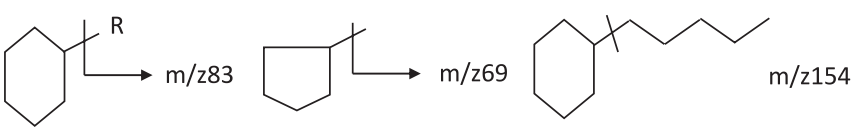

Figure 2. Cyclic hydrocarbons.
For the Balakhany deposit, the relationships between methylcyclohexane and the sum of cyclopentane hydrocarbons of composition $\mathrm{C}_{7}(0.55)$ have been studied. In all oil samples from the investigated deposit the presence of homologous series of $\mathrm{C}_{10}-\mathrm{C}_{25}$ alkylcyclohexanes has been proved (Figure 1S, Supporting Materials).

The literature ${ }^{[6]}$ contains data on the presence in the oils of homologous series of cyclohexanes with an isoprenoid chain, which according to scientists are of a relict nature. In the samples of oil isolated by us with use of computerized chromatography-mass spectrometry, isoprenoids with $\mathrm{m} / \mathrm{z}$ 183 have been determined.

In oils there are widely extended $\mathrm{C}_{10}$ bicyclanes and their methyl homologues. In particular, from the methyl decalin homologues in oils isolated from Balakhany soils, 3-methylbicyclo(4,4,0)- and 2-methylbicyclo(4,4,0)decanes, which are present almost in equal concentrations, were revealed (Figure $2 \mathrm{~S}$ ).

Tricyclic saturated hydrocarbons belong to the class of naphthenes that make up a significant part of oil hydrocarbons. The adamantane and its closest homologues (1-, 1,3and 1,3,5-methylsubstituted adamantanes) relating to the tricyclic saturated hydrocarbons were found in the investigated oil $^{[6]}$ (Figure 3).
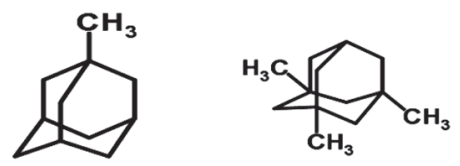

Figure 3. Adamantanes.

According to the study, ${ }^{[6]}$ the formation of hydrocarbons of the adamantane series in oils is a multi-stage reaction.

It should be noted that in some oils there are structures that under natural conditions are not capable of isomerizing into hydrocarbons of the adamantane series; they are isomerized with difficulty in the presence of aluminum bromide. This conclusion is based on the fact that in more transformed oils they are present in significant quantities, compared with less transformed ones. Obviously, the nature of the initial organic matter plays a decisive role in the formation of hydrocarbons of the adamantine series, and the presence or absence on the mass fragmenotgrams with $m / z 135,149$ and 163 of "protoadamantane" structures serves as the genetic feature.

Adamantane and its derivatives are used as medicines. The effective antioxidant and biological properties of some adamantylphenols have also been revealed.

In the oils on the Absheron Peninsula, tetracyclic structures are found, the core of which is the cyclopentanoperhydrophenantrene system, i.e. these compounds belong to the sterane hydrocarbons. Steranes, along with gopans, are the most important relic biologically marking hydrocarbons of oils. Structural formula of regular, i.e. ordinary steranes, corresponds to natural $\alpha$-cholestane having configuration of $5 \alpha \mathrm{H}, 14 \alpha \mathrm{H}, 17 \alpha \mathrm{H}, 20 \mathrm{R}$ of the corresponding chiral centers (Figure 4).

Steranes, as well as tricyclic hydrocarbons - derivatives of perhydrophenanthrene, are representatives of cyclic 


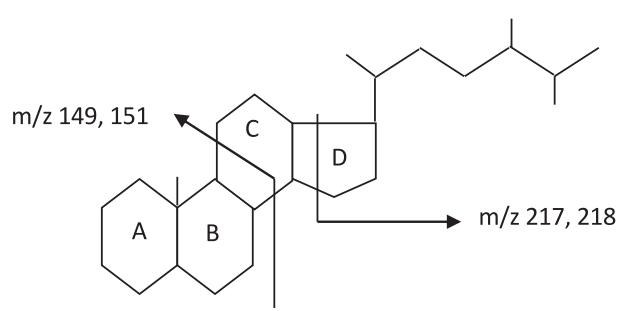

Figure 4. Steranes.

isoprenoid hydrocarbons, however, they are not found in all oils. Thus, they are absent in light oils that don't contain higher fractions. However, studies have shown that they are present in the oil samples investigated by us.

In the genetic plan the ratio of steranes $\mathrm{C}_{27}: \mathrm{C}_{28}: \mathrm{C}_{29}$ is of known interest. In Azerbaijani oils it is rather close and lies within the limits of $1.8-2.2 .^{[5]}$ For Balakhany oil it is $\mathrm{C}_{27}: \mathrm{C}_{28}: \mathrm{C}_{29}=28: 33: 38$.

Clear results (a much smaller background on the chromatogram) were obtained by constructing the mass fragmentograms for the most characteristic sterane ion or for a molecular ion with $m / z 217$ (Figure 3S).

For oil gopans $(17 \alpha)$, fragment $A$ is more intensive than fragment B. For biogopanes (17 $\beta)$, on the contrary, the intensity of fragment B is greater than the intensity of fragment A (Figure 5). Figure 4S shows a typical chromatogram of gopans with a fragmental ion $m / z 191$ characteristic for them, obtained by us for the investigated oil.

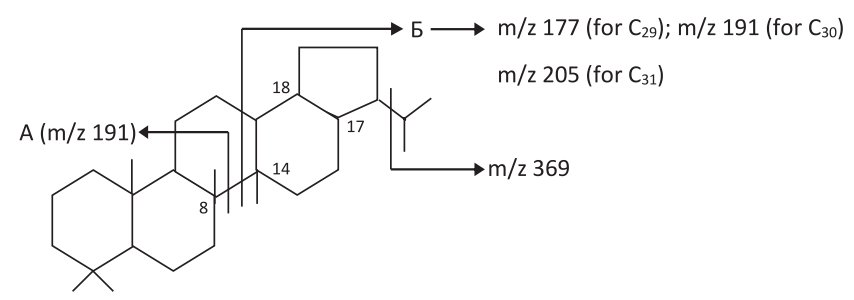

Figure 5. The main direction of the decay of gopans under the influence of electron impact.

For hydrocarbons of a number of gopans of composition $\mathrm{C}_{31}$ and higher, i.e. in cases when $\mathrm{C}-22$ atom becomes chiral, there may be two epimers that differ in $\mathrm{R}$ or $\mathrm{S}$ configuration of $\mathrm{C}-22$ chiral center. In the initial biogopans of composition $\mathrm{C}_{31}$ and higher, $\mathrm{C}-22$ atom has a strictly defined $R$ configuration. At the same time, the transition to oil gopans, in addition to the epimerization of $\mathrm{C}-17$, is accompanied by epimerization of C-22, which is manifested in a number of doublet peaks characteristic for chromatograms of mixed oil gopans. ${ }^{[1]}$ Figure $4 \mathrm{~S}$ shows the chromatogram of the mixed gopans obtained by us, on which doublet peaks characteristic for hydrocarbons of composition $\mathrm{C}_{31}$ and higher are clearly visible. In the computer processing of chromatograms, there are shown their reconstructions on the fragmental ion $\mathrm{m} / \mathrm{z}$ 191, most characteristic for gopans.
The relative distribution of gopans is considered as a characteristic "fingerprint" of the oils of the given sedimentation basin.

\section{Conclusions}

Comparison of biomarker mass fragmentograms of relict hydrocarbons, including steranes $(\mathrm{m} / \mathrm{z} 217)$ and gopans $(\mathrm{m} / \mathrm{z}$ 191) has shown that during the experiment under the influence of only natural climatic factors they retain the composition almost identical to the composition of the initial oil.

It follows from the above mentioned that in the environmental expertise associated with the identification of oil contaminated soils and the identification of the source of pollution, as well as monitoring the development of the situation in the contaminated area, it is desirable to use a complex of alkane, sterane and terpane indicators widely used in various geochemical studies.

\section{References}

1. Ashumov G.G. Azerbaijani Oils. Baku: Publishing House of Academy of Sciences of Azerb. SSR, 1961. 553 p. (in Russ.) [Ашумов Г.Г. Азербайджанские нефти. Баку: Издательство АН Азерб. ССР, 1961. 553 с.].

2. Ashumov G.G., Eyvazova S.F., Cherfas S.I. Card-file of Azerbaijani Oils. Baku: Publishing House of Academy of Sciences of Azerb. SSR, 1966. 68 p. (in Russ.) [Ашумов Г.Г., Эйвазова С.Ф., Черфас С.И. Картотека Азербайджсанских нефтей. Баку: Издательство АН Азерб. ССР, 1966. 68 с.].

3. Samedova F.I. Azerbaijani Oils and Their Component Composition. Baku: Elm, 2002. 247 p. (in Russ.) [Самедова Ф.И. Азербайджанские нефти и их компонентный состав. Баку: «Элм», 2002. 247 с.].

4. Samedova F.I., Huseynova B.A. Azerbaijani Oils of New Fields and Their Heteroatom Compounds. Baku: Elm, 2009. 323 p. (in Russ.) [Самедова Ф.И., Гусейнова Б.А. Азербайджанские нефти новых месторождений и их гетероатомные соединения. Баку: «Элм», 2009. 323 с.].

5. Samedova F.I. Azerbaijani Oils. Baku: Elm, 2011. 410 p. (in Russ.) [Самедова Ф.И. Нефти Азербайджана. Баку: «Элм», 2011. 410 c.].

6. Petrov A.A. Oil Hydrocarbons. Moscow: Nauka, 1984. 263 p. (in Russ.) [Петров А.А. Углеводороды нефти. М.: Наука, 1984. 263 c.].

7. Kayukova G.P., Negmedzinova L.Z., Romanov G.V., Sharipova N.S. Neftekhimiya 2004, 44(6), 440-448. (in Russ.).

8. Serebrennikova O.V., Belokon G.V. Geochemistry of Porphyrins. Novosibirsk: Nauka, 1984. 88 p. (in Russ.) [Серебренникова О.В., Белоконь Г.В. Геохимия порфиринов. Новосибирск: Наука, 1984. 88 с.].

9. Abidgildin Yu.M., Mikhaylyuk Yu.I., Yarullin K.S., Ratovskaya A.A. Porphyrins and Metalloporphyrin complexes of Oils. Moscow: Nauka, 1977. 88 p. (in Russ.) [Абыдгильдин Ю.М., Михайлюк Ю.И., Яруллин К.С., Ратовская А.А. Порфирины и металлопорфириновые комплексы нефтей. М.: Наука, 1977. 88 с.].

10. Babayev F.R. Azerbaidzhanskoe Neftyanoe Hozyaistvo 1975 , (3), 20-22 (in Russ.).

11. Serebrennikova O.V., Modjelina T.K., Beyko O.A. Neftekhimiya 1985, 25, 992-998 (in Russ.). 